strength and durability more costly varieties that have been imported from abroad.

Elwes tells us that it is doubtful when $Q$. Cerris, or the Turkey oak, was introduced into Great Britain, but since neither Evelyn nor other authorities up to his time mention it, we may safely assume that its introduction dated from about two hundred years ago, when it became very popular throughout the south of England.

English landscape and parklands have a worldwide reputation, and one of the most noticeable and characteristic features is the Turkey oak, which has a grace and beauty all its own. As Elwes emphasizes, it grows not only faster but also straighter than other oaks, and although somewhat similar in appearance there is a subtle difference. The rugged dark-coloured bark first attracts attention, which is afterwards turned towards the noble crown, more widely spreading than the common oak and adorned with a richer green and jagged leaf. The tree produces a very pretty mossy-cupped acorn. The colour of the timber is similar to that of the common oak. It has a bad reputation among craftsmen, as it is harder and heavier to work and more inclined to split in seasoning. It contains a larger proportion of sapwood than the common oak, the outer line of which quickly perishes. The inner line, when carefully dried off, becomes as hard and durable as the heartwood. I am inclined to think that it has boen used in the place of ordinary oak, and despite the difficulties already mentioned, I believe that with proper treatment it would be found as useful and durable as other kinds.

In Norway, Sweden and Finland, where the forest wealth plays a most important part in the economic life of the countries, I understand a day is set apart when men, women and children sot forth to plant trees. For nearly two hundred years the people of England have enjoyed or been spoilt by a pnosperity unequalled, if not unsarpassed, by any other country except Ameriea, which ominously reminds us of the state existing in the Roman Empire 1800 years ago. Tne contrast between the action of our forefathers, to whom we owe the inheritance of our woodlands, and later generations, is nowhere more clearly seen than in the direction of reafforestation.

I have been told that in the eighteenth century Admiral Collingwood used to walk out with his pockets full of acorns, which he distributed over his estate, and the owner of that country, which includes what is now called Chanctonloury Ring, used to ride or walk to the top of the hill every day during the season and sow beech mast or plant a tree.

No words of mine can better express the policy which should be adopted by the State to-day than those written by Evelyn 260 years ago :

"And if thus His Majesty's forests and chases were stored, viz. with this spreading tree at handsome intervals .. benignly visited with the gleams of the sun ... nothing could be more ravishing. ... We should find such goodly plentations for the boast of our rangers, and forests infinitely preferable to anything we have yet beheld, rude and neglected as they are today, when his Majesty shall proceed, .... to animate the laudable pride into fashion, forests \& woods .... will present us with another face, than now they do. And here I cannot but applaud the worthy industry of old Sir Harbotle Irmistone, whe I am told from a very small nursery of acerns which he sowed in the neglected corners of his grounds did draw forth such numbers of Oaks of competent growth ... and did wonderfully improve both the beauty and the value of his desmesnes."

\section{TESTING WOOD PRESERVATIVES}

N $\mathrm{N}$ artiele by J. Loutritz (Bell Lab. Rec., 22, No. A 4 ; December 1943) describes laboratory and outdoor tests made on wood preservatives used for impregnating polos for communication lines. Sticks $\frac{3}{4}$ in. square and about $3 \mathrm{ft}$. long are cut from boards of southern pine sapwood, the uniform size of these samples facilitating calculation of the wood density and the amount of preservative retainerd, as both are based on volume.

Laboratory tests on preservatives are now earried out in an experimental cylinder by either full- or empty-cell methods. For the former, the air is evacuated from the eylinder containing the specimens, and after a specified time the cylinder is filled with preservative, air pressure being applied to force the latter into the wood cells; about $30 \mathrm{lb}$. of preserv. ative can be injected per cu. ft. of wood. In the emptycell treatment the cylinder air pressure is raised to from 25 to $50 \mathrm{lb} / \mathrm{sq}$. in. Then the preservative is pumped in, and the pressure is raised still higher to force the preservative into the wood. Upon releasing the pressure, the expansion of the initial air trapped by the preservative forces out the excess from the wood, and theoretically only the cell wall is coated. Vacuum is applied after the pressure is released to empty the cells more eompletely. The initial air pressure largely determines the amount of preservative which will be forced out of the cells, while the difference between the initial and final pressures controls the distribution and penetration.

About twenty sticks are selected for each charge and the sample is weighed before and after treatment, the gain being taken as the basis for calculating the amount of preservative retained. Then the sticks are cut at the centre to give specimens treated under identical conditions for comparison by the laboratory rot test and by field exposures. For field-exposure tests the specimens are buried to a depth of 7 in. in a uniform distribution throughout the test plot. They are examined once a year and the amount of decay at and below the ground-line is rated. Since some specimens survive several years or do not fail under exposure tests, a time rating was devised which takes into consideration their past performance.

When a preservative shows promising results in laboratory and field tests, larger material of fencepost size and eventually $10 \mathrm{ft}$. posts are treated and exposed in 'test gardens'.

\section{ELECTROSTATIC ELECTRON LENSES}

A $\mathrm{N}$ article by $\mathrm{K}$. Spangenberg and L. M. Field (Elec. Comm., 21, No. 3; 1943) describes and discusses the measured characteristics of a number of electrostatic lenses, giving the characteristic curves of nine different lenses belonging to three basic types. The forms tested were cylinder lenses of various spacings and diameter-ratios, aperture lenses (parallel plates with circular apertures on the beam axis) of various spacings, and, for comparisons, a lens formed by a cylinder and an aperture in a plate. By interpolating between the sets of curves given, approximate predictions of the properties of lenses of slightly different spacings or diameter-ratio may be made. The test method employed makes use of a 